Gut, 1977, 18, 156-160

\title{
Transmission of rotavirus gastroenteritis from children to a monkey
}

\author{
J. D. Mitchell, L. A. LAMBETh, L. SOSUlA, A. MURPHY, AND \\ M. ALBREY
}

From the University of New South Wales Department of Paediatrics and Pathology, Prince of Wales Children's Hospital, Sydney, and the Institute of Clinical Pathology and Medical Research, Lidcombe, NSW, Australia

SUMMARY A pooled suspension of rotavirus was prepared from the stools of eight children with acute non-bacterial gastroenteritis. The suspension was infused into the duodenum and stomach of an infant monkey (Nemestrina macaque). Biopsy samples of duodenal mucosa were taken at several intervals after inoculation, examined by light and electron microscopy, and assayed for lysosomal activity. Virus-like particles were seen within and around microvilli and intracellularly within vesicles as early as 20 minutes after the infusion. On the fourth and fifth days, large lysosomal bodies containing numerous virus-like particles were found within epithelial cells of the duodenal villi. No such particles were seen in the pre-inoculation sample or at days 16 or 25 after infection. The present study would appear to be the first demonstration of the transmission of this human virus to another species.

An aetiological association between a viral agent and acute non-bacterial gastroenteritis of infants has been observed in many areas of the Western world (Bishop et al., 1973; Orstavik et al., 1973; Flewett et al., 1974; Middleton et al., 1974). This agent has been termed a rotavirus, orbivirus, and a duovirus. Passage of the closely related viruses causing Nebraska calf diarrhoea (NCD) and epizootic diarrhoea of infant mice (EDIM) has been achieved in their respective host species (Banfield et al., 1968; Stair et al., 1973).

No suitable animal host has been found for the human virus. The possibility of significant species specificity prompted us to investigate the monkey as a potential host animal for the human agent.

\section{Methods}

Stored faecal specimens $\left(-15^{\circ} \mathrm{C}\right)$ from 11 children admitted to hospital with acute gastroenteritis during an epidemic period in July-August 1974 were processed for the rotavirus. Each specimen was suspended in $20 \% \mathrm{v} / \mathrm{v} 0.9 \%$ saline and centrifuged at $20000 \mathrm{~g}$ for 30 minutes. The resultant supernatant was then centrifuged at $100000 \mathrm{~g}$ for 90 minutes. The final deposit was resuspended in $0.5 \mathrm{ml}$ distilled water and negatively stained with $2 \%$ potassium phosphotungstate (pH 6.7). The material was examined on a Formvar coated grid Received for publication 12 August 1976 with a Philips 300 electron microscope. Rotavirus particles were identified in eight of the 11 specimens. The positive samples were combined and stored at $-15^{\circ} \mathrm{C}$ after the removal of an aliquot for culture. No bacteria known to cause diarrhoea were grown from the fluid.

A 5 month old monkey (Nemestrina macaque) from a colony at the Prince of Wales Children's Hospital was used in this study. No episodes of diarrhoea had been observed in this colony in the preceding five years. The monkey was isolated and fed on a diet of fresh fruit, rat cubes, and tap water. Control stool and duodenal biopsies were collected and 24 hours later, $3 \mathrm{ml}$ of the pooled suspension of rotavirus was infused into the duodenum via a sterile biopsy capsule. Twenty minutes after the infusion, the biopsy capsule was fired to obtain a duodenal biopsy sample. During withdrawal of the instrument, an additional $2 \mathrm{ml}$ of the virus suspension was infused into the stomach. The animal was subsequently observed for clinical evidence of gastroenteritis. Stool specimens were collected daily for six days after inoculation and less frequently thereafter. Biopsy samples of duodenal mucosa were obtained on the fourth, fifth, and 16th days, and when the animal was killed under anaesthesia 25 days after inoculation. All operative procedures were performed under keiamine hydrochloride anaesthesia. Duodenal biopsies were performed using a modification of a method applied to 
young infants. Metaclopromide $(1 \mathrm{mg})$ was given intravenously before inserting a paediatric biopsy capsule under fluoroscopic control. Portions of each duodenal biopsy sample were processed for light and electron microscopy. The remainder was frozen in liquid nitrogen and stored at $-70^{\circ} \mathrm{C}$ for enzyme analysis.

For electron microscopy, the mucosa was fixed in $3 \%$ glutaraldehyde in $0.1 \mathrm{M}$ Sorensen's phosphate buffer (pH 7.6) for one hour. The tissue was washed overnight and fixed in $2 \%$ osmium tetroxide in the same buffer. After dehydration in ethanol and embedding in Araldite, thin ( $800 \AA)$ sections were stained with uranyl acetate and lead citrate. For light microscopy, the sections were stained with haematoxylin and eosin or with methyl green pyronin. Lysosomal enzymes (acid phosphatase, $\mathrm{N}$-acetyl- $\beta$-glucosaminidaae, and arylsulphatase) were assayed using 4-methyl umbelliferyl derivatives (Koch-Light Laboratories) as described elsewhere (Mitchell et al., 1974).

\section{Results}

A 12 hour period of watery diarrhoea, beginning 96 hours after inoculation, was the only clinical evidence of infection seen in the monkey. This episode was managed by restricting intake to glucose and water for 24 hours, after which there were no ill effects on return to a normal diet.

Virus-like particles were seen under the electron microscope in three of the post-inoculation duodenal mucosal specimens. Epithelial cells from the sample obtained 20 minutes after instillation of the virus into the duodenum showed many virus-like particles either within or between microvilli and also intracellularly within cytoplasmic vesicles near the Golgi region. These particles showed a dense central core surrounded by a less dense outer coat.

Epithelial cells from the samples obtained on days four and five after inoculation were characterised by the appearance of large, irregularly shaped cytoplasmic inclusions (Fig. 1). Many such inclusions were partly or completely surrounded by a single limiting membrane suggesting that they were lysosomal bodies. In less mature epithelial cells at the bases of villi and near the crypt surfaces, these inclusions were filled with virus-like particles and often with condensations of electron dense material (dense bodies). At the tips of villi, the inclusions were larger (up to two-thirds the width of the cell)

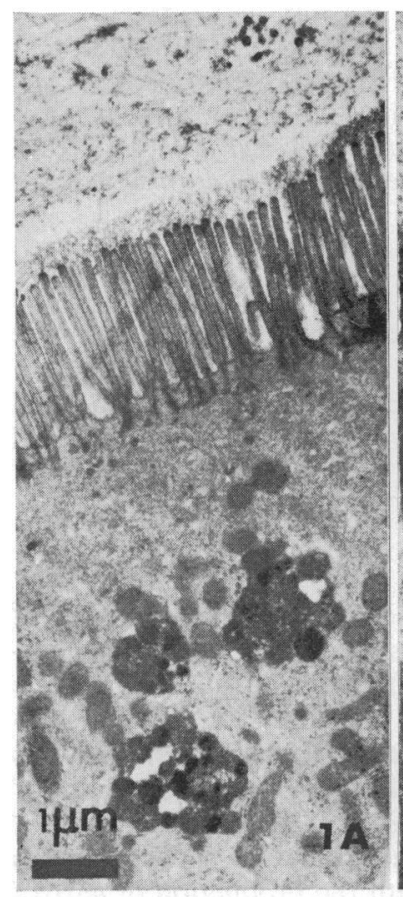

(a)

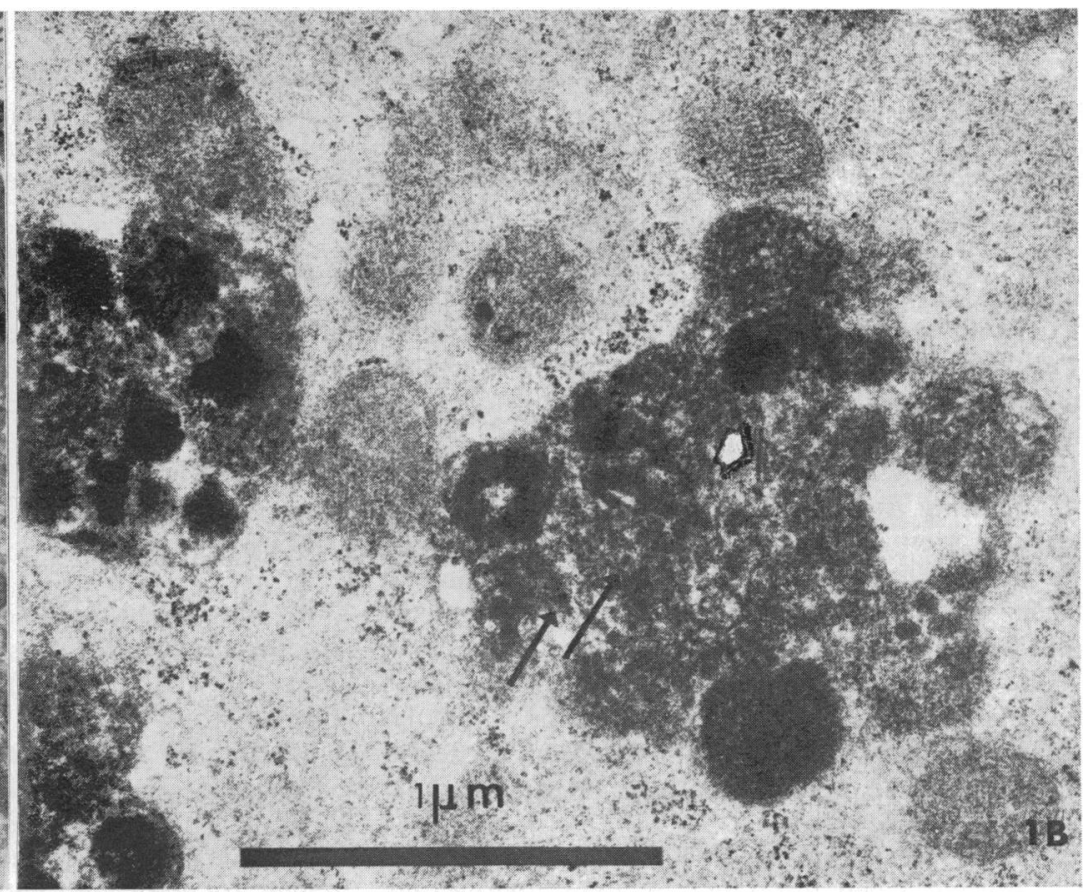

(b)

Fig. 1 a. Duodenal epithelial cell at day 4 after inoculation. Three large cytoplasmic inclusions are present near the microvillus border of the cell. b. Detail of cytoplasmic inclusion shown in Fig. 1a. Viral particles (arrows) are seen within the inclusion. An open arrow points to an elongated form. 


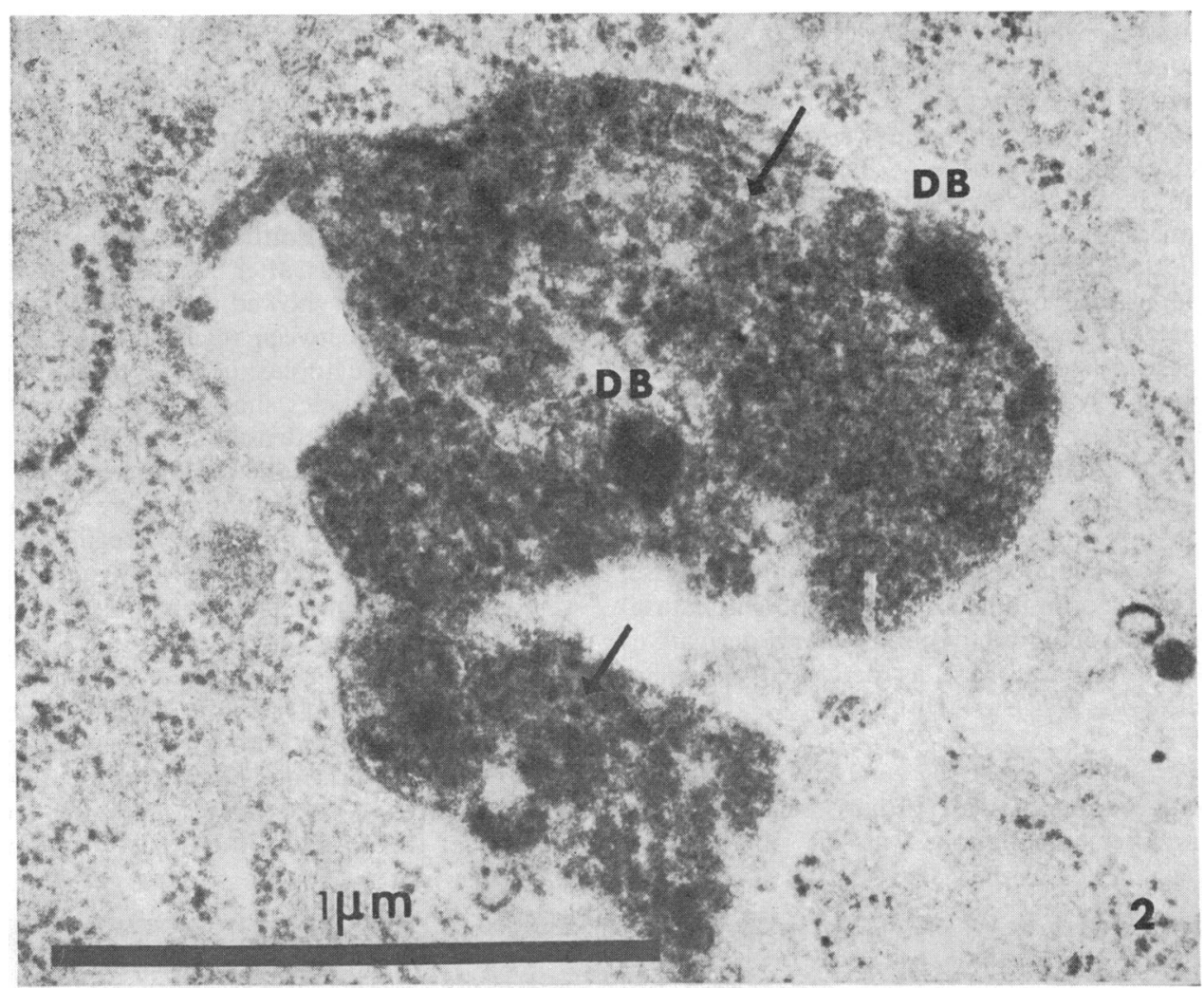

Fig. 2 A large cytoplasmic inclusion form from a mid-villous duodenal epithelial cell in the day 4 post-inoculation sample. The inclusion is partly surrounded by a single limiting membrane and contains numerous viral particles. The protein coat of some particles gives the appearance of radiating spicules (arrows). Dense bodies (DB) are also seen.

and less homogeneous because of the presence of myelin figures as described in secondary lysosomes (Parker et al., 1965). Virus-like particles within inclusions varied in diameter from $44 \mathrm{~nm}$ to $61 \mathrm{~nm}$ and contained central cores of variable density surrounded by an outer coat giving the appearance of radiating spicules (Fig. 2). Only rarely were particles seen to have an outer envelope. Despite the size of intracellular inclusions the structure of other subcellular organelles, including the microvilli, was preserved.

Electron microscopy of the pre-inoculation tissue and that obtained on days 16 and 25 post-inoculation revealed no virus particles. Lysosomes present in epithelial cells were of small diameter and devoid of any virus-like particles.

The duodenal mucosal histology of all samples was normal when examined by light microscopy. Specimens from days four and five after inoculation contained discrete pyronin positive cytoplasmic inclusions within epithelial cells situated near the tips of villi.
Rotavirus particles could not be positively identified in any of the stool specimens from the monkey.

There were no significant differences in lysosomal enzyme activities between the various duodenal mucosal samples.

\section{Discussion}

The ultrastructural evidence of viral invasion of duodenal epithelial cells, combined with the occurrence of diarrhoea after the instillation of the human rotavirus into the monkey further substantiates an aetiological relationship between this virus and acute non-bacterial gastroenteritis of infancy. This agent appears to belong to a group of morphologically and antigenically similar viruses which are associated with the production of gastroenteric infection in the young of a number of mammalian species (Banfield et al., 1968; Stair et al., 1973; Kapikian et al., 1975).

The morphological changes seen in the present 
study differ in some respects from those reported with infection due to human, EDIM, or NCD viruses in their respective host species (Banfield et al., 1968; Mebus et al., 1971; Bishop et al., 1973). This may be due to such factors as (1) modification of the viral reproductive cycle after inoculation using only small numbers of virus particles; (2) varying virus pathogenicity between neonatal infection and that occurring at a later age; or (3) modification of pathogenicity due to passage outside the host species.

Virus particles seen in the 20 minute sample appeared to be entering the cell by passage into the microvilli and by pinocytosis between microvilli. However, serial sections would be needed to confirm this process. Virus particles were also seen in vesicles near the Golgi region at this stage. By the fourth and fifth days, virus particles could be seen only within large, discrete intracytoplasmic bodies bounded by a single membrane, consistent with a lysosomal morphology. Similar localisation of virus particles to these intracytoplasmic sites has been shown for reovirus type 3 infection of a cultured cell line (Silverstein and Dales, 1968). The type 3 reovirus cycle involved rapid localisation within small vesicles followed by appearance within lysosomes during a $\mathbf{3 0}$ minute period from cellular ingestion. Viral coat protein was removed with exposure of the RNA nucleoid, followed by viral factory appearance and progeny virus invasion of cell cytoplasm. Our findings suggest that a similar cycle may occur with infection due to the human rotavirus.

Further support for a lysosomal phase during the viral replication cycle can be seen in photographs published elsewhere, which show both the NCD virus (Stair et al., 1973) and the human virus (Suzuki and Kono, 1975) in association with membrane-bound lysosomal-like collections with a striking similarity to those observed in the present study.

The cytoplasmic inclusions seen by light microscopy in the epithelial cells at the tips of villi in the present study were pyronin positive, consistent with the presence of RNA virus particles.

Our inability to detect virus particles in the monkey's stools may reflect the sensitivity of our stool purification method or indicate unusually low yields of replicated virus under the conditions of this experiment.

Reovirus type 3 infection of cultured cells was shown not to affect lysosomal enzyme activity despite localisation of the virus within these organelles (Silverstein and Dales, 1968). The findings in the present study are in agreement with this observation. The lack of any difference in lysosomal enzyme activity between different biopsy samples, despite the electron microscopic evidence of a considerable increase in lysosomal content of epithelial cells at days four and five after inoculation, tends to confirm our observation that the major component of the lysosomes at this time appeared to be viral material.

The human rotavirus has been shown to multiply in organ culture of human embryonic gut (Wyatt et al., 1974) and it is likely that multiplication in monolayer culture will soon be achieved. However, optimum progress in this important field will require an appropriate animal model and, despite the obvious limitations imposed by a single animal experiment, we believe that the present study has shown that the monkey will be a suitable animal. The potential to perform studies which include sequential small intestinal biopsy sampling is an additional advantage for considering the primate in all future animal studies.

We thank Dr Earle Owen and Mr K. Bryant and acknowledge the generosity of the Children's Surgical Research Fund of the Prince of Wales Children's Hospital for the supply of the monkey used in this study. We also thank Miss K. Ewing for expert technical assistance, Mr K. Deason of the Department of Medical Illustration, Prince of Wales Hospital, and the nursing staff of the Children's Ward, Sutherland Hospital, Sydney, for collecting samples from the children with gastroenteritis.

\section{References}

Banfield, W. G., Kasnic, G., and Blackwell, J. H. (1968). Further observations on the virus of epizootic diarrhoea of infant mice. Virology, 36, 411-421.

Bishop, R. F., Davidson, G. P., Holmes, I. H., and Ruck, B. J. (1973). Virus particles in epithelial cells of duodenal mucosa from children with acute non-bacterial gastroenteritis. Lancet, 2, 1281-1283.

Flewett, T. H., Bryden, A. S., and Davies, H. (1973). Virus particles in gastroenteritis. Lancet, 2, 1497.

Kapikian, A. Z., Cline, W. L., Mebus, C. A., Wyatt, R. G., Kalica, A. R., James, H. D., Van Kirk, D., Chanock, R. M., and Kim, H. W. (1975). New complement fixation test for the human reovirus-like agent of infantile gastroenteritis. Lancet, 1, 1056-1061.

Mebus, C. A., Stair, E. L., Underdahl, N. R., and Twiehaus, M. J. (1971). Pathology of neonatal calf diarrhoea induced by a reo-like virus. Veterinary Pathology, 8, 490-505.

Middleton, P. J., Szymanski, M. T., Abbott, G. D., Bortolussi, R., and Hamilton, J. R. (1974). Orbivirus acute gastroenteritis of infancy. Lancet, 1, 1241-1244.

Mitchell, J. D., Mitchell, J., and Peters, T. J. (1974). Enzyme changes in human small bowel mucosa during culture in vitro. Gut, 15, 805-811.

Orstavik, I., Figenschau, K. J., and Ulstrup, J. C. (1974) 
Rotavirus in stored specimens of faecal extracts. Lancet, 2, 1083.

Parker, J. W., Wakasa, H., and Lukes, R. J. (1965). The morphologic and cytochemical demonstration of lysosomes in lymphocytes incubated with phytohemagglutinin by electron microscopy. Laboratory Investigation, 14, 1736-1743.

Silverstein, S. C., and Dales, S. (1968). The penetration of reovirus RNA and initiation of its genetic function in L-strain fibroblasts. Journal of Cell Biology, 36, 197-230.

Stair, E. L., Mebus, C. A., Twiehaus, M. J., and Underdahl, N. R. (1973). Neonatal calf diarrhoea. Electron micro- scopy of intestines infected with a reovirus-like agent. Veterinary Pathology, 10, 155-170.

Suzuki, H., and Kono, T. (1975). Reovirus-like particles in jejunal mucosa of a Japanese infant with acute infectious non-bacterial gastroenteritis. Tohoku Journal of Experimental Medicine, 115, 199-211.

Wyatt, R. G., Kapikian, A. Z., Thornhill, T. S., Sereno, M. M., Kim, H. W., and Chanock, R. M. (1974). In vitro cultivation in human fetal intestinal organ culture of a reovirus-like agent associated with non-bacterial gastroenteritis in infants and children. Journal of Infectious Diseases, 130, 523-528.

\section{The January 1977 Issue}

\section{THE JANUARY 1977 ISSUE CONTAINS THE FOLLOWING PAPERS}

Detection, by three techniques, of hepatitis B surface antigen (HBsAg) and determination of $\mathrm{HBsAg}$ and anti-HBs titres in patients with chronic liver disease MARIA CHIARAMONTE, JENNY HEATHCOTE, M. CREES, AND SHEILA SHERLOCK

Speed of change in biliary lipids and bile acids with chenodeoxycholic acid-is intermittent therapy feasible? J. H. ISER, G. M. MURPHY, AND R. HERMON DOWLING

Amylase creatinine clearance ratio after biliary surgery L. A. DONALDSON, W. MCINTOSH, AND S. N. JOFFE

Controlled trial of synthetic D-penicillamine and prednisone in maintenance therapy for active chronic hepatitis R. B. STERN, S. P. WILKINSON, P. J. N. HOWORTH, AND ROGER WILLIAMS

Vitamin B $_{6}$ deficiency in chronic liver diseaseevidence for increased degradation of pyridoxal-5'phosphate D. LABADARIOS, J. E. ROSSOUW, J. B. MCCONNELL, M. DAVIS, AND ROGER WILLIAMS

Correlation between hepatic morphology and immunoglobulins and antibodies to Escherichia coli in cirrhosis HANNE PRYTZ, M. BJøRNEBOE, P. CHRISTOFFERSEN, H. POULSEN, AND F. ØRSKOV

Zinc in ulcerative colitis: a therapeutic trial and report on plasma levels M. W. DRONFIELD, J. D. G. MALONE, AND M. J. S. LANGMAN

Consequences of partial and subtotal colectomy in the rat P. C. MASESA AND J. M. FORRESTER
Lactate dehydrogenase isoenzyme pattern in uninvolved mucosa of patients with colorectal carcinOMa ROSALIND TAYLER, V. H. CUMBERLAND, AND D. W. PIPER

Reinvestigation of lactose intolerant children: lack of correlation between continuing lactose intolerance and small intestinal morphology, disaccharidase activity, and lactose tolerance tests MARY HARRISON AND J. A. WALKER-SMITH

Coxsackie and mumpsvirus infection in a prospective study of acute pancreatitis C. W. IMRIE, J. C. FERGUSON, AND R. G. SOMMERVILLE

Basal gastric secretion: reproducibility and relationship with duodenal ulceration R. G. FABER AND M. HOBSLEY

Significance of Ca-soap formation for calcium absorption in the rat G. GACS AND D. BARLTROP

Sulphasalazine in asymptomatic Crohn's disease

A multicentre trial

Nitrite and thiocyanate in the fasting and secreting stomach and in saliva W. S. J. RUDDELL, L. M. BLENDIS, AND C. L. WALTERS

Controlled trial of Duogastrone in duodenal ulcer W. A. DAVIES AND P. I. REED

Books

Notes and activities

Copies are still available and may be obtained from the PUBLISHING MANAGER, BRITISH MEDICAL ASSOCIATION, TAVISTOCK SQUARE, LONDON WC1H 9JR, price $£ 2.75$, including postage 